\title{
Immunological Features of Respiratory Syncytial Virus-Caused Pneumonia-Implications for Vaccine Design
}

\author{
Emma Rey-Jurado ${ }^{1}$ and Alexis M. Kalergis ${ }^{1,2, *}$ \\ 1 Millennium Institute on Immunology and Immunotherapy, Departamento de Genética Molecular y \\ Microbiología, Facultad de Ciencias Biológicas, Pontificia Universidad Católica de Chile, \\ Santiago 8330644, Chile; erey@bio.puc.cl \\ 2 Departamento de Endocrinología, Facultad de Medicina, Pontificia Universidad Católica de Chile, \\ Santiago 8330644, Chile \\ * Correspondence: akalergis@bio.puc.cl; Tel.: +56-922-686-2842
}

Academic Editor: Susanna Esposito

Received: 31 December 2016; Accepted: 26 February 2017; Published: 4 March 2017

\begin{abstract}
The human respiratory syncytial virus (hRSV) is the causative agent for high rates of hospitalizations due to viral bronchiolitis and pneumonia worldwide. Such a disease is characterized by an infection of epithelial cells of the distal airways that leads to inflammation and subsequently to respiratory failure. Upon infection, different pattern recognition receptors recognize the virus and trigger the innate immune response against the hRSV. Further, T cell immunity plays an important role for virus clearance. Based on animal studies, it is thought that the host immune response to hRSV is based on a biased T helper (Th)-2 and Th17 T cell responses with the recruitment of T cells, neutrophils and eosinophils to the lung, causing inflammation and tissue damage. In contrast, human immunity against RSV has been shown to be more complex with no definitive $\mathrm{T}$ cell polarization profile. Nowadays, only a humanized monoclonal antibody, known as palivizumab, is available to protect against hRSV infection in high-risk infants. However, such treatment involves several injections at a significantly high cost. For these reasons, intense research has been focused on finding novel vaccines or therapies to prevent hRSV infection in the population. Here, we comprehensively review the recent literature relative to the immunological features during hRSV infection, as well as the new insights into preventing the disease caused by this virus.
\end{abstract}

Keywords: human respiratory syncytial virus; pneumonia; host immunity; vaccines and therapies

\section{Introduction}

Pneumonia is defined as pathological inflammation of the lungs. According to the World Health Organization (WHO), pneumonia caused 920,136 child deaths in 2015, thereby making it a major public health burden worldwide [1]. Further, not only children are affected by pneumonia but also the elderly, with 53,000 deaths reported annually in the $>65$ years old population in the United States alone [2]. Clinical studies of childhood pneumonia contributed to the definition of pneumonia as a respiratory rate higher than $50 / \mathrm{min}$, fever and chest in-drawing [3]. Symptoms of pneumonia may include chest pain, wheezing and breathing difficulties [4]. Pneumonia is primarily due to infectious agents, such as viruses, bacteria and fungi. Streptococcus pneumoniae and Klebsiella pneumoniae are the most common bacterial etiology, whereas the human respiratory syncytial virus (hRSV), influenza and rhinovirus are the more frequent viral causal agents of pneumonia $[5,6]$. Furthermore, virus and bacteria co-infections are usually observed in about $40 \%$ of patients with community-acquired pneumonia [7]. 
hRSV is one of the predominant causal viruses of pneumonia [8] and is also the main agent causing acute lower respiratory tract infections (ALRTIs), affecting children younger than five years old and the elderly [9]. Mild manifestations of hRSV include rhinorrhea, cough, congestion, low-grade fever, reduced appetite and respiratory distress [10]. However, hRSV can also cause severe symptoms, such as alveolitis, bronchiolitis and pneumonia [10]. Moreover, recently, extra pulmonary manifestations, such as encephalitis, cardiopathy and hepatitis have been reported [11-14]. Importantly, global mortality due to hRSV-associated ALRTI in children younger of 5 years is estimated to be from 66,000 to 199,000 deaths per year [15]. The cost in medical health expenses on hospitalizations due to hRSV infections has been estimated to be 394 million USD per year [16]. To note, risk factors associated to severe cases of hRSV include elderly, age under 2 or 3 months, premature birth, chronic lung disease, congenital heart disease, simultaneous infections $[17,18]$ and immunosuppression $[19,20]$. Around $36 \%$ of individuals can be reinfected at least once during the winter season [21]. Along these lines, such reinfections could be caused by deficient humoral and cellular immunity response after the first virus encounter [21,22].

$\mathrm{hRSV}$ is an enveloped, negative sense, single stranded RNA virus belonging to the recently defined Pneumoviridae family, Orthopneumovirus genus. The viral genome is non-segmented RNA, $15.2 \mathrm{~kb}$ in length, which encodes eleven proteins and the following ten genes: NS1-NS2-N-P-M-SH-F-G-M2-L (from $3^{\prime}$ to $5^{\prime}$ ) $[23,24]$. The Fusion (F), Glycoprotein (G) and Small Hydrophobic (SH) proteins are expressed at the surface whereas the Nucleoprotein $(\mathrm{N})$, Phosphoprotein $(\mathrm{P})$, large polymerase protein (L), Matrix protein (M) and M2-1 proteins are below the virus envelope $[25,26]$. The F protein is in charge of the fusion of the viral envelope with the host membrane [27-30]. On the other hand, the G protein has been shown to mediate the attachment of hRSV to the cell membrane [31] and the fusion of the F protein with the host cell membrane [32]. In contrast, the $\mathrm{SH}$ protein has been defined as a viroporin, thereafter allowing the entrance of low molecular weight molecules and modifying the cell permeability $[26,33]$. The L, P, M2-1 and N hRSV proteins constitute the ribonucleoprotein (RNP), which encapsides the viral RNA [34,35]. From this complex, the L protein regulates the replication and transcription of the hRSV RNA and the N protein is thought to protect viral RNA from nucleases $[23,36]$. The P protein is essential for the RNP complex and its phosphorylation may be required for the virus replication in vitro and in vivo [34]. M2-1 protein, which also is part of the RNP complex, promotes the transcription of all hRSV genes [37]. Likewise, M2-2 protein mediates the "switch" from transcription to RNA replication [38]. Besides from structural proteins, the hRSV genome also includes two non-structural proteins called NS1 and NS2. Finally, as another hRSV protein, the matrix protein $\mathrm{M}$ that promotes viral assembly is required for $\mathrm{hRSV}$ replication.

Animal studies have shown that hRSV infection is characterized by the recruitment of infiltrating immune cells to the lungs, thereby producing lung damage and pulmonary inflammatory hyper reactivity. Such pulmonary inflammation is due to a Th-2 biased immune response, constituted of high levels of IL-4 and IL-13 cytokines. On the contrary, T helper (Th)- 1 response, producing cytokines such as Interferon (IFN)- $\gamma$ and IL-2, has been associated with disease control and virus clearance. While such cytokine patterns have been shown in animal models, infant patients from 3 weeks to 24 months of age with acute phase hRSV bronchiolitis showed a decrease of IFN- $\gamma+$ and an increase of IL- $4+\mathrm{CD} 4^{+}$ and $C D 8^{+} \mathrm{T}$ cells [39]. Further, patients with hRSV bronchiolitis showed a decrease in the proportion of $\gamma \delta \mathrm{T}$ cells producing IFN $\gamma$ in response to mitogen stimulation [40].

Here, we discuss the host immune response associated to hRSV infection focusing on hRSV-associated pneumonia, the evasion of the immune response by the virus, as well as the prophylaxis and vaccines under development to prevent the disease caused by this pathogen.

\section{Host Immune Response Associated to hRSV-Pneumonia}

hRSV is the major infectious agent for bronchiolitis, which is characterized by infection and inflammation of the distal bronchiolar airways. In addition, hRSV is also a causal agent of severe pneumonia. hRSV-caused pneumonia is characterized by the infection of alveolar lung regions, thereby triggering an alveolar inflammation that can eventually result in severe pulmonary disease with 
hypoxia and respiratory failure [41]. At the lungs, airway epithelial cells (AECs), macrophages and dendritic cells (DCs) represent the first cells encountering hRSV. Upon infection, different pattern recognition receptors (PRRs) in these cells trigger a downstream innate immune cascade, including Toll-like receptors (TLRs), retinoic acid-inducible gene I (RIG-I)-like receptor (RLR) family members and NOD-like receptors (NLR) [42] (Figure 1). At this point, different proteins of the hRSV have been found to interact with the host to modulate the innate immune response. The F protein has been shown to interact with several host proteins, such as Toll-like receptor (TLR) 4, intercellular adhesion molecule 1 (ICAM-1) and nucleolin [43,44]. Moreover, the SH protein has also been found to activate the NOD-like receptor family, pyrin domain containing 3 (NLRP3), thereby triggering the activation of the inflammasome [45]. On the other hand, the N protein was shown to colocalize and interact with RIG-I-like receptors, the mitochondrial antiviral signalling (MAVS) protein and the melanoma differentiation-associated gene 5 (MDA5), thereby modulating the downstream innate immune response [46] (Figure 1). Indeed, such study also demonstrated an interaction between MDA5 and N protein within inclusion bodies, suggesting that hRSV may be "sequestering" these important proteins required to trigger the triggering innate immune response [46]. As a result of MDA5 sequestration, a decrease of type I IFN production is observed, which hampers the control of hRSV infection. The NLRP3 receptor, a member of the NLR family, together with proteins, such as caspase-1 and the Pyrin domain containing NLRs known as NALP proteins, constitute the inflammasome responsible for the production of IL-1 $\beta$ and IL-18 $[47,48]$. Thus, it has been shown that hRSV triggers NLRP3 inflammasome by the SH protein [45] (Figure 1).

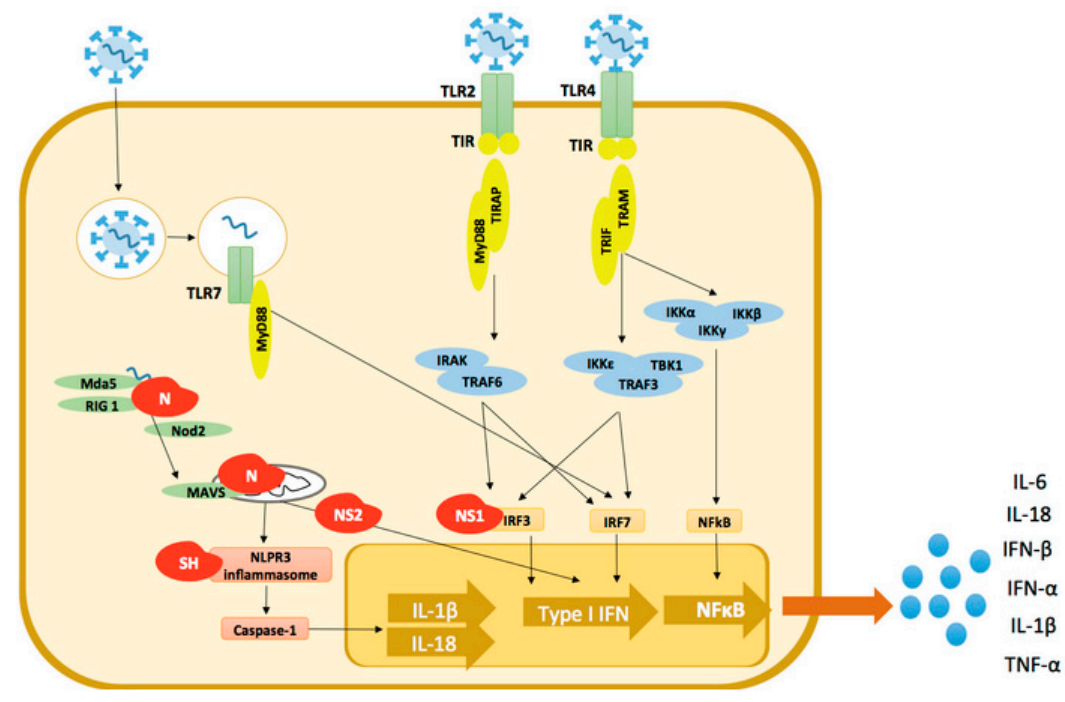

Figure 1. Mechanisms used by hRSV to evade host innate immunity. TLR, Toll-like receptor; RIG-I, retinoic acid-inducible gene-1; NOD, nucleotide-binding oligomerization domain; MDA5, melanoma differentiation-association gene 5; MAVS, mitochondrial antiviral signalling; NLPRP3, NOD-like receptor family pyrin domain containing 3; MyD88, Myeloid differentiation primary response gene 88; TIR, Toll-interleukin 1 receptor; TRAF, TNF receptor associated factor; IKK, Interleukin-1 receptor-associated kinase; IKK $\beta$, inhibitor of nuclear factor $\kappa B$ kinase subunit beta; IRF, Interferon regulatory factor. The human respiratory syncytial virus (hRSV) is recognized by different pattern recognition receptors (PRRs) including TLR-2, TLR-4, TLR-7, RIG-I and NOD2. hRSV can also enter via endocytosis and viral RNA can be recognized inside the endosome by TLR-7. Thereafter, a cascade of inflammatory response is activated. Different proteins of the hRSV have been found to interfere in the innate response against the infection. The nucleoprotein $(\mathrm{N})$ has been suggested to "sequester" MDA5, RIG-I and MAVS proteins interfering in the type I IFN production. Besides from N, both non-structural (NS)1 and NS2 proteins have been shown to inhibit the IFN production at the MAVS and IRF3 level. On the other hand, the small hydrophobic (SH) protein has been shown to activate the NLPRP3 inflammasome, eventually triggering the production of IL-1 $\beta$ and IL-18. 
Such an hRSV infection promotes the recruitment of immune cells to the site of the challenge. Further, hRSV infection generates the virus-associated immunopathology characterized by up-regulation of proinflammatory cytokines including thymic stromal lymphopoetin (TSLP), Interleukin (IL)-4, IL-6, IL-10 and IL-13 and infiltration of mononuclear cells (mainly T cells), neutrophils and eosinophils (Figure 2) [49-52]. These cytokines fail to achieve hRSV clearance, herein favoring the persistence of the virus. To note, the TSLP together with the epithelial cell-derived IL-7, an IL-7-like cytokine, IL-25 and IL-33 are characteristic of acute asthma exacerbations and Th-2 polarized response during virus infections [53]. Likewise, increased expression of TSLP has been found in asthmatic children after hRSV infection [54]. Consistent with this notion, studies in animal models suggest that hRSV infection could predispose to asthma, however additional research would be needed to clearly understand such an association [55]. Further, TSLP has been shown in mice to induce functional maturation of myeloid DCs (mDCs) [50] and an increased expression of molecules that polarize to a Th-2 response. It is also thought that hRSV can directly impair the function of chemokines and cytokines because the $G$ protein colocalizes with host proteins, such as CX3CR1 in ciliated lung cells [56]. Such pathogenic inflammation leads to an unbalanced Th-2 and Th-17 response with low production of interferon (IFN)- $\gamma$, which contributes to lung damage and ameliorates virus clearance $[57,58]$. Most of these data are derived from animal models, however low production of IFN- $\gamma$ has also been observed in patients suffering from hRSV bronchiolitis [39,40]. Importantly, the IL-17A produced at the airways after hRSV infection has been linked to neutrophil infiltration to the lungs [59]. Likewise, high levels of IL-17 have been related with hRSV bronchiolitis [60] and with community-acquired pneumonia [61].

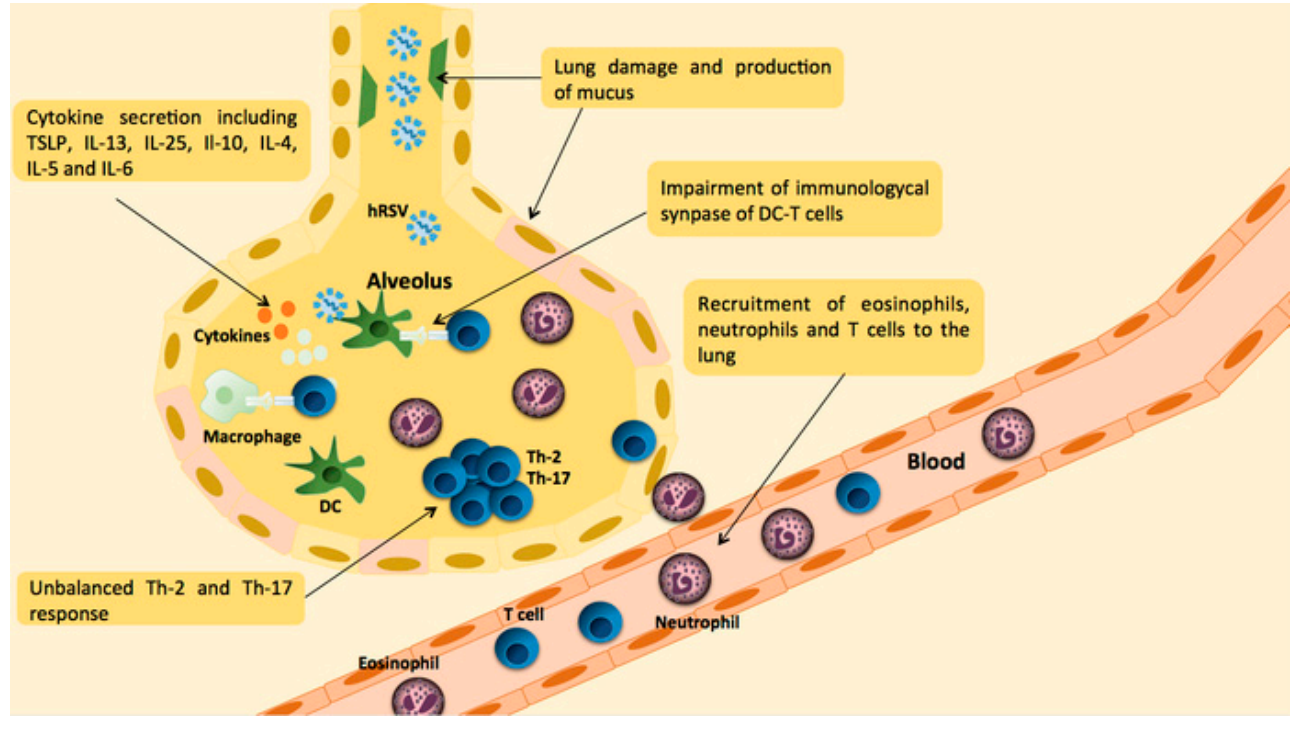

Figure 2. Airway inflammation due to hRSV infection. Upon hRSV infection, airway epithelial cells, dendritic cells and macrophages recognize hRSV. Such recognition triggers a downstream innate response, which eventually will result in the production of cytokines and chemokines such as thymic stromal lymphopoetin (TSLP), IL-13, IL-25, Il-10, IL-4, IL-5 and IL-6. Likewise, such hRSV infection promotes the recruitment of neutrophils, eosinophils and T cells. Such inflammatory response results in Th-2 and Th-7 response, mucus production and lung damage.

Furthermore, hRSV infection causes an inhibition of IFN $\alpha / \beta$ production by plasmacytoid DCs [51], which is thought to be due to the ability of both NS1 and NS2 proteins to impair the activation of the type I IFN response cascade. NS1 protein inhibits the phosphorylation of Interferon Regulatory Factor 3 (IRF-3), thereby inhibiting the activation of the IFN gene promotor and blocking the JAK/STAT signaling pathway. On the other hand, the NS2 protein interacts with RIG-I preventing the activation of IRF-3 [62,63] (Figure 1). Likewise, DCs infected with NS1- and NS2-deficient hRSV displayed 
higher expression of cell surface DC maturation markers, such as CD80, CD83, CD86 and CD38, as compared with DCs challenged with wild type hRSV. Herein, it is thought that NS1 and NS2 inhibit DC maturation by interfering with the activation of the type I IFN response. This notion is supported by the observation that DC maturation induced by NS1- and NS2-deficient hRSV is suppressed by IFN neutralization [64]. Consistently, hRSV induces only low to moderate maturation in human DCs, which is observed both in infected DCs as well in neighboring cells [65]. Further, although hRSV can promote maturation in mouse DCs, these cells are rendered incapable of activating naive T cells [66,67], which is consistent with an inefficient $\mathrm{T}$ cell response against hRSV infection [68]. It has been suggested that inefficient $\mathrm{T}$ cell activation by hRSV-infected DCs results from an impaired assembly of the immunological synapse between DCs and T cells [69]. Interestingly, the N protein of hRSV has been shown to be involved in the inhibition of immunological synapse assembly (Figure 2) [70]. Therefore, both inhibition of DC maturation and an inefficient $\mathrm{T}$ cell response during hRSV infection could explain the reduced IFN- $\gamma$ production observed in bronchiolitis patients.

Both $\mathrm{CD} 4^{+}$and $\mathrm{CD} 8^{+} \mathrm{T}$ cells have been shown to be crucial for the establishment of an efficient anti-hRSV immunity [71]. Interestingly, these immune cells play a pivotal role during hRSV infection and can be either beneficial or detrimental for the host. Along these lines, human cytotoxic $\mathrm{CD} 8^{+} \mathrm{T}$ cells (CTLs) have been shown to recognize peptides derived from N, SH, F, M and NS1 proteins bound to MHC class I molecules and thereby contribute to the clearance of the virus [72,73]. However, it has also been suggested that depletion of $\mathrm{CD} 8^{+} \mathrm{T}$ cells can reduce the hRSV-associated severity in mice [74]. In addition to effector $\mathrm{CD} 4^{+}$and $\mathrm{CD} 8^{+} \mathrm{T}$ cells, regulatory $\mathrm{T}$ (Treg) can contribute to modulating hRSV infection. This notion is supported by the observation that depletion of $\mathrm{CD} 4^{+} \mathrm{FOXP} 3^{+} \mathrm{CD} 25^{+}$cells leads to an exacerbated inflammation pathology with higher weight loss and neutrophil infiltration into the lungs upon hRSV infection [75,76].

\section{Prophylaxis against hRSV Infection}

Children hospitalized because of severe cases of hRSV-associated pneumonia are a major public health burden worldwide. Prophylaxis against hRSV infection is intended to prevent hRSV infection-derived illness during virus outbreaks or after a potential exposure to the virus.

\subsection{Antibody-Mediated Prophylaxis/Passive Immunization}

\subsubsection{Current Monoclonal Antibody against hRSV}

Currently, palivizumab (Synagys ${ }^{\circledR}$, Medimmune, Inc., Gaithersburg, MD, USA), an $\operatorname{IgG}_{1}$ humanized monoclonal antibody, is the only licensed therapy to prevent severe lung disease caused by hRSV in high-risk infants. High-risk factors for hRSV disease include prematurity, bronchopulmonary dysplasia, congenital health disease, cancer, cystic fibrosis, down syndrome, neuromuscular syndrome and immune deficiency syndromes [77]. Palivizumab neutralizes an epitope of the hRSV F protein and has been demonstrated to inhibit the cell-to-cell fusion and the transcription of the virus [78]. Up to a $55 \%$ reduction in hospitalizations for high-risk infants during hRSV outbreaks can be obtained by the use of palivizumab $[79,80]$. Despite proven effectiveness, palivizumab requires intramuscular monthly injections throughout the hRSV outbreak, which is costly and unaffordable for most public health systems (near US\$ 780 for the $50 \mathrm{mg}$ vial and US\$ 1416 for $100 \mathrm{mg}$, with a $15 \mathrm{mg} / \mathrm{kg}$ recommended dosage). In addition to the high cost, adverse events including hypersensitivity reactions have been reported in infants treated with palivizumab [81].

\subsubsection{Other Monoclonal Antibodies against hRSV}

To improve safety and cost/efficacy, different approaches have been explored to improve the efficiency and specificity of the passive prophylaxis against hRSV (Table 1). One promising result was motavizumab, also known as MEDI-524, a monoclonal antibody derived from palivizumab by modifying the complementary determining regions. This monoclonal antibody showed increased 
affinity to the F protein as compared to palivizumab [82]. Motavizumab displayed a higher neutralizing activity and an improved capacity to prevent hRSV pathology compared to palivizumab in animal models [83]. Moreover, clinical trials to evaluate safety and pharmacokinetics of motavizumab obtained results equivalent to palivizumab [84-86]. However, no significant reduction of viral loads nor severity of hRSV-caused illness were found in infected infants treated with motavizumab, as compared with placebo controls [87]. It is important to mention that skin rashes, as an adverse event in motavizumab treated patients, were observed in all studies $[84,85,88]$. In 2010, the Food and Drug Administration (FDA) declined to license motavizumab to treat high-risk hRSV infants, in part because this monoclonal antibody offered the same efficacy as palivizumab. Due to these previous results with monoclonal antibodies, currently, molecular strategies are focused on improving the neutralizing capacity but also on reducing the observed adverse effects. Promising results with derivatives of motavizumab have been reported $[89,90]$. These monoclonal antibodies contain a modified Fc region, are well tolerated and show up to 100 days of half-life in human subjects [89]. Such an extended half-life together with higher levels of hRSV neutralizing antibodies as compared to palivizumab has also been reported with an anti-hRSV prefusion F monoclonal antibody, known as Medi8897 [90]. A phase II clinical trial in healthy preterm infants is currently in progress [91]. Due to the fact that both $F$ and $G$ are on the virus surface, the $\mathrm{G}$ protein has also been explored as an antigen to target hRSV. Indeed, anti-hRSV $\mathrm{G}$ monoclonal antibodies were also able to reduce pulmonary inflammation associated with hRSV in BALB/c mice [92,93]. However, to date, no clinical results have been reported for antibodies that target this protein as an $\mathrm{hRSV}$ antigen.

\subsubsection{Maternal Immunization against hRSV}

Another strategy for vaccine research against hRSV has been maternal immunization. It was previously demonstrated that RSV-neutralizing antibodies are transferred efficiently through the placenta from pregnant women to newborns [94]. Consistently, studies in cotton rats showed that pups gestated by hRSV-primed mothers were protected from viral replication in the lungs [95]. Further, maternal immune protection was also observed in lambs after immunization with a subunit vaccine based on the F protein of hRSV with an adjuvant ( $\Delta \mathrm{F} /$ TriAdj). Promisingly, those newborns that received maternal antibodies showed less virus production and lung pathology as compared with control animals [96]. Immunization with a vaccine has already been found to be safe and immunogenic in healthy women of childbearing age in a phase II clinical trial [97]. This recombinant $F$ nanoparticle formulation is currently on phase III clinical trial on women of childbearing age during their third-trimester of pregnancy and a phase III clinical trial in older adults with this formulation has been recently completed $[98,99]$.

\subsection{Active Immunization}

The first approach to prevent hRSV was the formaldehyde-inactivated hRSV vaccine, which caused an exacerbated respiratory disease characterized by excessive inflammation with a Th-2 biased response [100]. Indeed, up to $80 \%$ of hospitalizations in children receiving this vaccine were reported [101,102]. Therefore, after that negative experience, therapies and vaccines approaches against the hRSV have been focused on achieving high immunogenicity but without promoting the exacerbated respiratory disease. Approximately sixty hRSV vaccine candidates are undergoing preclinical or clinical development at the moment [103]. A summary of the vaccines currently under research to prevent the hRSV infections is shown in Table 1. 
Table 1. Current research on therapies and vaccines against hRSV infection.

\begin{tabular}{|c|c|c|c|}
\hline Name & Strategy & Preclinical/Clinical studies & References \\
\hline Motavizumab/MEDI-524 & Anti-F Monoclonal antibody & $\begin{array}{l}\text { Better neutralizing activity than palivizumab. Phase I, II and III clinical studies show similar } \\
\text { results to palivizumab and some adverse events. }\end{array}$ & [84-88] \\
\hline Motavizumab/MEDI-8897 & Anti-F Monoclonal antibody & $\begin{array}{l}\text { High levels of hRSV neutralizing antibodies. Phase I clinical studies show good tolerance and } \\
\text { extended half-life of the antibody. Phase II in healthy preterm infants is ongoing. }\end{array}$ & [89-91] \\
\hline $\mathrm{mAb} 131-2 \mathrm{G}$ & Anti G Monoclonal antibody & Reduces pulmonary inflammation in BABL/c mice. & {$[92,93]$} \\
\hline Recombinant $\mathrm{F}$ nanoparticle & Anti-F Polyclonal & $\begin{array}{l}\text { Maternal immunization has been shown to protect lambs and cotton rat newborns. } \\
\text { Immunogenic in healthy women of childbearing age (Phase I and II studies). Phase III in women } \\
\text { in their third-trimester of pregnancy is ongoing and phase III is completed in older adults. }\end{array}$ & [95-99] \\
\hline $\begin{array}{l}\text { Combination of RSV F VLP, G } \\
\text { VLP, and RSV F DNA }\end{array}$ & $\begin{array}{l}\text { RSV F DNA prime and VLPs containing F and } \\
\text { G boost }\end{array}$ & $\begin{array}{l}\text { Induces hRSV F specific IgG2a antibodies, neutralizing antibodies and prevents lung disease in } \\
\text { BALB/c mice. }\end{array}$ & [104] \\
\hline SV pcD-F & DNA vaccine encoding RSV-F protein & $\begin{array}{l}\text { Topical vaccine induces cellular and mucosal immune response and reduces cell infiltration to } \\
\text { the lungs in BALB/c mice. }\end{array}$ & [105] \\
\hline rB/HIPV3 & $\begin{array}{l}\text { Recombinant parainfluenza virus (rB/HPIV3) } \\
\text { expressing the G and F RSV proteins }\end{array}$ & High quality hRSV-neutralizing antibodies in hamsters. & [106] \\
\hline rBCG-N-hRSV & BCG expressing N RSV protein & $\begin{array}{l}\text { Protection against hRSV infection in mice with reduction of inflammation, hRSV specific } \mathrm{T} \text { cell } \\
\text { response and RSV antibodies in serum. }\end{array}$ & {$[71,107,108]$} \\
\hline RSV LID $\Delta \mathrm{M} 2-2$ & $\begin{array}{l}\text { Live attenuated vaccine, M2-2 RSV } \\
\text { protein deleted }\end{array}$ & $\begin{array}{l}\text { Immunogenic in chimpanzees. Phase I clinical study showed hRSV attenuation and RSV F } \\
\text { serum IgG antibody responses. }\end{array}$ & [109] \\
\hline RSV D46 cp $\Delta \mathrm{M} 2-2$ & $\begin{array}{l}\text { Live attenuated vaccine, M2-2 RSV } \\
\text { protein deleted }\end{array}$ & Phase I in progress. & [103] \\
\hline RSV Medi $\Delta \mathrm{M} 2-2$ & $\begin{array}{l}\text { Live attenuated vaccine, M2-2 RSV } \\
\text { protein deleted }\end{array}$ & Phase I in progress. & [103] \\
\hline RSV $\Delta$ NS2 $\Delta 1313$ & $\begin{array}{l}\text { Live attenuated vaccine, NS2-2 RSV } \\
\text { protein deleted }\end{array}$ & Demonstrated a stable formulation. Phase I in progress. & [110] \\
\hline RSV cps2 & $\begin{array}{l}\text { Attenuated cold-passaged respiratory } \\
\text { syncytial virus }\end{array}$ & Phase I in progress. & [103] \\
\hline SeVRSV & $\begin{array}{l}\text { Sendai virus (SeV)-based live intranasal } \\
\text { vaccine that expresses the full length RSV } \\
\text { fusion }(\mathrm{F}) \text { gene }\end{array}$ & Protects cotton rats from hRSV challenge in a cotton rat maternal antibody model. & [111] \\
\hline Delta-G RSV & Recombinant RSV lacking the G gene & $\begin{array}{l}\text { Induces long-lasting protection against hRSV challenge and resulted in no detectable replication } \\
\text { of hRSV in lungs and nasal washes in cotton rats. }\end{array}$ & [112] \\
\hline
\end{tabular}


Table 1. Cont.

\begin{tabular}{|c|c|c|c|}
\hline Name & Strategy & Preclinical/Clinical studies & References \\
\hline OE4 & $\begin{array}{l}\text { Live attenuated vaccine, codon-reoptimization of } \\
\text { RSV NS1, NS2 and G and deletion of SH proteins }\end{array}$ & Proven stability and no enhanced disease in cotton rats and mice. & [100] \\
\hline NE-RSV & Nanoemulsion-inactivated RSV & Prevents hRSV-immunopathology and promotes Th- $1 /$ Th- 17 responses in BALB/c mice & [113] \\
\hline VLPs F & VLPs containing F RSV protein & $\begin{array}{l}\text { High levels of neutralizing antibodies, Th-1 mediated response and protects against lung } \\
\text { hRSV infection }\end{array}$ & [114] \\
\hline VLPs F and G & VLPs containing $\mathrm{F}$ and $\mathrm{G}$ proteins & $\begin{array}{l}\text { Protects against RSV disease by reducing cell infiltration to the lung, weight loss and } \\
\text { lung damage. }\end{array}$ & [115] \\
\hline DPX-RSV-SH & VLPs containing SH protein & Protection in cotton rats and mice. Phase I clinical trial showed safety. & {$[116,117]$} \\
\hline RSV BLP & $\begin{array}{l}\text { Bacterium-like particles (BLP)s containing } \\
\text { F antigen }\end{array}$ & Protection in cotton rats and mice. & {$[118,119]$} \\
\hline N-FsII-nanorings & $\begin{array}{l}\text { Nanorings able to display the epitope of the } \\
\text { human RSV F antigenic site }\end{array}$ & Protects against hRSV disease, however, they did not find detectable neutralizing antibodies & [120] \\
\hline Viaskin ${ }^{\circledR}-\mathrm{N}$ & Patches loaded with $\mathrm{N}$-nanorings & $\begin{array}{l}\text { Protects against hRSV in pigs and is delivered efficiently through the skin and reaches } \\
\text { Langerhans cells. }\end{array}$ & [121] \\
\hline G+CSA & Recombinant $\mathrm{G}$ protein with cyclosporine A & Induces Treg cells, controlling the hRSV-immunopathology. & [116] \\
\hline RSV F & $\begin{array}{l}\text { RSV fusion protein stabilized in the native } \\
\text { prefusion conformation }\end{array}$ & Induces neutralizing antibodies and prevents viral challenge in cotton rats. & [117] \\
\hline RSV G & G protein polypeptide and peptide vaccination & Prevents hRSV pathology and inhibit hRSV replication in mice. & [122] \\
\hline RSV F protein & RSV postfusion F protein & Protection against hRSV challenge and antibody responses in BALB/c mice. & [123] \\
\hline RSV-PreF & $\begin{array}{l}\text { RSV protein F vaccine engineered to maintain } \\
\text { prefusion conformation. }\end{array}$ & hRSV neutralizing antibody responses in Phase I clinical trial. & [124] \\
\hline DNA RSV & $\begin{array}{l}\text { DNA expressing soluble hRSV-F in combination } \\
\text { with an AdV expressing the same antigen }\end{array}$ & $\begin{array}{l}\text { Systemic DNA prime-tonsillar booster immunization regimen and induces the recruitment of } \\
\text { hRSV-F-specific T cells to and/or expansion of the T cells in the respiratory tract in } \\
\text { non-human rimates }\end{array}$ & [125] \\
\hline Ad5.RSV-F & Adenovirus expressing F RSV protein & Immunogenic in mice and cotton rats. Phase I currently in progress. & [126-128] \\
\hline MVA & $\begin{array}{l}\text { Modified vaccine Ankara virus expressing } \\
\text { hRSV proteins }\end{array}$ & Protection in macaques. Safe and immunogenic in adults. Phase III currently in progress. & [129-131] \\
\hline $\begin{array}{l}\text { rPIV5-RSV-F and } \\
\text { rPIV5-RSV-G }\end{array}$ & Vaccine based on Parainfluenza virus 5 (PIV5) & Generation of serum neutralizing mice and no enhanced disease upon hRSV challenge in mice. & [132] \\
\hline PanAd3-RSV & Vaccine based on Simian adenovirus & Phase I clinical trial in progress. & [131] \\
\hline
\end{tabular}




\subsubsection{Live Attenuated Vaccines}

The strategy of live attenuated vaccines was explored early to prevent hRSV disease. Current live attenuated vaccines have been engineered by reverse genetics. For instance, the deletion of M2-2 protein was used to obtain three candidates of attenuated vaccines [133]. One of them, known as hRSV LID $\triangle \mathrm{M} 2-2$, has already shown stability, hRSV attenuation and anti-F serum IgG antibody responses in phase I clinical trials [109]. The other two candidates with the deletion of the M2-2 protein are currently under evaluation in phase I clinical trials [103]. Further, attenuating NS2 gene deletion has been explored as a strategy to develop a live attenuated RSV vaccine [110], which is currently in phase I clinical evaluation. Likewise, codon-reoptimization of NS1, NS2 and G, together with the deletion of SH proteins led to the generation of a stable attenuated hRSV vaccine, known as OE4 [134], which showed protection and lack of disease enhancement in mice and cotton rats [134].

\subsubsection{Recombinant Vector Vaccines against hRSV}

In addition to live attenuated vaccines, recombinant vectored vaccines have also been explored for generating hRSV vaccines. For instance, Parainfluenza virus type 3 (PIV3) has been used as a vector to express hRSV proteins of interest $[135,136]$. Thus, recombinant bovine/human PIV3 (rB/HPIV3) expressing the $\mathrm{G}$ and $\mathrm{F}$ proteins can induce high anti-hRSV serum titers as well as protection against the virus in hamsters $[136,137]$. Recently, a partially stabilized prefusion form of the F protein was included in the genome of $\mathrm{rB} / \mathrm{HPIV} 3$ to achieve higher quality of anti-hRSV-neutralizing antibodies in hamsters and rhesus monkeys than the previous formulation [106]. Also, the PIV type 5 (PIV5) has been shown to be an effective vector to express $\mathrm{F}$ and $\mathrm{G}$ proteins of hRSV, herein offering protection against the virus in mice [132].

Another successful recombinant approach to generate recombinant vaccines against hRSV was the Bacille Calmette-Guérin (BCG), which can efficiently express hRSV proteins [71,107]. BCG is an attenuated strain of Mycobacterium bovis and by itself displays a strong immunogenic capacity that promotes the production of Th- 1 type cytokines, which are required to reduce hRSV dissemination and disease. Based on these properties, BCG was engineered to express various hRSV antigens [71]. Importantly, immunization with recombinant BCG strains expressing M2 or N proteins conferred protection against $\mathrm{hRSV}$ in mice and led to an early $\mathrm{T}$ cell recruitment to the lungs. Immunized animals showed no lung damage, lower viral loads and a Th1/Th2 balance after a challenge with hRSV [71,107]. Furthermore, a single dose of rBCG-N-hRSV manufactured under Good Manufacturing Practices (GMP) was shown to maintain those immunological properties and promoted long-lasting immunity in mice [108].

Furthermore, adenovirus has also been used as a vector to express hRSV antigens. Up to seven hRSV vaccine candidates have used adenovirus as a vector [103]. Adenovirus vectors expressing the hRSV F protein were immunogenic in mice and in cotton rats [126-128]. Further, the vaccine known as PanAd3-RSV showed protection against hRSV in calves [138] and a Phase I clinical trial has been recently completed [131]. On the other hand, baculovirus expressing the F protein in combination with virus-induced signalling adaptor reduced Th-2 responses and the immunopathology associated to hRSV infection $[139,140]$. Moreover, the F protein of hRSV and the hemagglutinin-neuraminidase protein of PIV were inserted into the Sendai virus genome to generate a vaccine inducing long-lasting protection against both hRSV and PIV in cotton rats [141]. Finally, a modified vaccine Ankara virus expressing hRSV proteins was shown to protect against virus infection in macaques $[129,130]$ and to be safe and immunogenic in adults. Phase III clinical trials are currently ongoing for this vaccine [142].

\subsubsection{Virus-Like Particles (VLPs) as Vaccines for hRSV}

Virus-like particles (VLPs), which consist of viral proteins assembled without genetic material, have also been used as a vaccine strategy against hRSV [114,115]. Thus, it was shown that VLPs containing the matrix protein of the human metapneumovirus (hMPV) together with the recombinant 
postfusion and prefusion F hybrids of hRSV promoted high levels of neutralizing antibodies, a Th-1 mediated response and protected against lung RSV infection [114]. Likewise, a combination of VLPs containing $\mathrm{F}$ and $\mathrm{G}$ proteins together with F-encoding plasmid DNA was found to be protective against hRSV disease by reducing weight loss and lung inflammatory damage [143]. Moreover, the bacterium-like particle (BLP) technology has also been used to develop a mucosal vaccine by including the F protein as an antigen to protect against hRSV. Such a RSV BLP vaccine reduced virus titers and resulted in higher titers of F-specific IgG in sera from cotton rats and mice challenged with hRSV [116]. Further, a Phase I clinical trial is in progress to assess the safety, reactogenicity and tolerability of two intranasal dose levels of this vaccine [117]. Further, the SH protein has also been underscored recently as a new target for vaccination against hRSV. As a vaccine candidate approach, a peptide derived from the $\mathrm{SH}$ ectodomain (SHe) was conjugated to the keyhole limpet hemocyanin [144]. This vaccine showed protection against hRSV and induced high levels of SH-specific IgGs in cotton rats and mice, however, sera from these animals showed no neutralizing capacity against hRSV [144]. Further, a phase I clinical trial was conducted with an hRSV vaccine containing the SH antigen and a novel adjuvant DepoVax or SH antigen co-administered with aluminum hydroxide, showing safety in vaccinated subjects [145].

Nanomedicine has appeared in the last few years to contribute to hRSV research vaccines. The reason for using such a technology is because it has been postulated that the density of the immunogens could be key for triggering the humoral immune response [146]. Nanoparticles technology can assemble several antigens in sizes ranging from 2 to $200 \mathrm{~nm}$, thereby creating a high density "cocktail antigen". Specifically, a high density of viral antigens facilitates antibody secretion and the formation of memory B cells [146]. Along these lines, a nanoparticle vaccine based on the F protein of hRSV was shown to be well tolerated in a Phase I clinical trial. Further, this vaccine was immunogenic in humans and led to high microneutralization antibody titers against the hRSV A Tracy and hRSV B strains. Further, this trial showed that the F hRSV nanoparticle vaccine induced an immune response against the epitope antigen site II by adding palivizumab in competitive assays [147]. In addition, this vaccine formulation was also used for maternal immunization as previously described [97]. Other VLPs with nanoparticles expressing hRSV glycoproteins also showed immunogenicity and the authors of the study demonstrated that alveolar macrophages are responsible for preventing detrimental infiltration by neutrophils, eosinophils and $\mathrm{T}$ cells, as well as mucus and inflammatory cytokine production [148]. Soluble nanorings composed of $\mathrm{N}$ protomers containing the epitope of the hRSV F targeted by palivizumab, known as N-FsII-nanorings, are another strategy [120]. Mice immunized with N-FsII-nanorings were protected from hRSV-caused disease, however, they showed no detectable neutralizing antibodies [120]. Moreover, patches loaded with $\mathrm{N}$-nanorings have been found to protect against hRSV in pigs and have been demonstrated to be delivered efficiently through the skin and to reach Langerhans cells [121].

\section{Concluding Remarks}

The severe cases of pneumonia associated to hRSV infection are still a major public health burden worldwide and currently there are no licensed vaccines available. The only licensed treatment to prevent hRSV infections is the Palimizumab, an anti-F hRSV protein humanized monoclonal antibody that can reduce hRSV-associated hospitalizations by up to $55 \%$, however, at a high cost [149]. Nowadays, several studies are in progress to generate a vaccine against hRSV, including live attenuated, viral-like particles and passive immunizations. Nevertheless, currently, there are few studies on human clinical trials or that have proven long-lasting immunity. Thus, new vaccines and therapies are urgently needed to reduce the high rate of hospitalizations caused by hRSV.

Acknowledgments: This work was supported by the Millennium Institute on Immunology and Immunotherapy from Chile (P09/016-F for AMK), CONICYT/FONDECYT POSTDOCTORADO No. 3160249, FONDECYT grants number: 1150862, 1070352, 1050979, 1040349, 1100926, 1110397, 1131012, 1140010, 1140011, 3140455. Biomedical Research Consortium (BMRC 13CTI-21526 for AMK). FONDEF grant D11I1080. 
Conflicts of Interest: The authors declare no conflict of interest.

\section{References}

1. WHO. Pneumonia. Avaliable online: http://www.who.int/mediacentre/factsheets/fs331/en/ (accessed on 28 February 2017).

2. CDC. Pneumonia. Atlanta, GA: US Department of Health and Human Services, CDC, 2016. Avaliable online: http:/ / www.cdc.gov/pneumonia/index.html (accessed on 28 February 2017).

3. Scott, J.A.G.; Wonodi, C.; Moïsi, J.C.; Deloria-Knoll, M.; DeLuca, A.N.; Karron, R.A.; Bhat, N.; Murdoch, D.R.; Crawley, J.; Levine, O.S.; et al. The definition of pneumonia, the assessment of severity, and clinical standardization in the pneumonia etiology research for child health study. Clin. Infect. Dis. 2012, 54, S109-S116. [CrossRef] [PubMed]

4. Nascimento-Carvalho, A.C.; Ruuskanen, O.; Nascimento-Carvalho, C.M. Comparison of the frequency of bacterial and viral infections among children with community-acquired pneumonia hospitalized across distinct severity categories: A prospective cross-sectional study. BMC Pediatr. 2016, 16, 105. [CrossRef] [PubMed]

5. $\quad$ El Seify, M.Y.; Fouda, E.M.; Ibrahim, H.M.; Fathy, M.M.; Husseiny, A.A.A.; Khater, W.S.; El Deen, N.N.; Abouzeid, H.G.; Hegazy, N.R.; Elbanna, H.S. Microbial etiology of community-acquired pneumonia among infants and children admitted to the pediatric hospital, Ain Shams University. Eur. J. Microbiol Immunol 2016, 6, 206-214. [CrossRef] [PubMed]

6. Bashir, U.; Nisar, N.; Arshad, Y.; Alam, M.M.; Ashraf, A.; Sadia, H.; Kazi, B.M.; Zaidi, S.S. Respiratory syncytial virus and influenza are the key viral pathogens in children $<2$ years hospitalized with bronchiolitis and pneumonia in islamabad pakistan. Arch. Virol. 2016. [CrossRef]

7. Voiriot, G.; Visseaux, B.; Cohen, J.; Nguyen, L.B.; Neuville, M.; Morbieu, C.; Burdet, C.; Radjou, A.; Lescure, F.X.; Smonig, R.; et al. Viral-bacterial coinfection affects the presentation and alters the prognosis of severe community-acquired pneumonia. Crit. Care 2016, 20, 375. [CrossRef] [PubMed]

8. Jain, S.; Williams, D.J.; Arnold, S.R.; Ampofo, K.; Bramley, A.M.; Reed, C.; Stockmann, C.; Anderson, E.J.; Grijalva, C.G.; Self, W.H.; et al. Community-acquired pneumonia requiring hospitalization among U.S. children. N. Engl. J. Med. 2015, 372, 835-845. [CrossRef] [PubMed]

9. Calvo, C.; Garcia-Garcia, M.L.; Blanco, C.; Vazquez, M.C.; Frias, M.E.; Perez-Brena, P.; Casas, I. Multiple simultaneous viral infections in infants with acute respiratory tract infections in spain. J. Clin. Virol. 2008, 42, 268-272. [CrossRef] [PubMed]

10. Collins, P.L.; Melero, J.A. Progress in understanding and controlling respiratory syncytial virus: Still crazy after all these years. Virus Res. 2011, 162, 80-99. [CrossRef] [PubMed]

11. Sweetman, L.L.; Ng, Y.T.; Butler, I.J.; Bodensteiner, J.B. Neurologic complications associated with respiratory syncytial virus. Pediatr. Neurol. 2005, 32, 307-310. [CrossRef] [PubMed]

12. Eisenhut, M. Extrapulmonary manifestations of severe respiratory syncytial virus infection-A systematic review. Crit. Care 2006, 10, R107. [CrossRef] [PubMed]

13. Esposito, S.; Salice, P.; Bosis, S.; Ghiglia, S.; Tremolati, E.; Tagliabue, C.; Gualtieri, L.; Barbier, P.; Galeone, C.; Marchisio, P.; et al. Altered cardiac rhythm in infants with bronchiolitis and respiratory syncytial virus infection. BMC Infect. Dis. 2010, 10, 305. [CrossRef] [PubMed]

14. Kirin, B.K.; Topic, R.Z.; Dodig, S. Hepatitis during respiratory syncytial virus infection-A case report. Biochem. Med. 2013, 23, 112-116. [CrossRef]

15. Nair, H.; Nokes, D.J.; Gessner, B.D.; Dherani, M.; Madhi, S.A.; Singleton, R.J.; O’Brien, K.L.; Roca, A.; Wright, P.F.; Bruce, N.; et al. Global burden of acute lower respiratory infections due to respiratory syncytial virus in young children: A systematic review and meta-analysis. Lancet 2010, 375, 1545-1555. [CrossRef]

16. Paramore, L.C.; Ciuryla, V.; Ciesla, G.; Liu, L. Economic impact of respiratory syncytial virus-related illness in the us: An analysis of national databases. PharmacoEconomics 2004, 22, 275-284. [CrossRef] [PubMed]

17. Prendergast, A.J.; Klenerman, P.; Goulder, P.J. The impact of differential antiviral immunity in children and adults. Nat. Rev. Immunol. 2012, 12, 636-648. [CrossRef] [PubMed]

18. Vanden Driessche, K.; Persson, A.; Marais, B.J.; Fink, P.J.; Urdahl, K.B. Immune vulnerability of infants to tuberculosis. Clin. Dev. Immunol. 2013, 781320. [CrossRef] [PubMed] 
19. Miller, R.F.; Loveday, C.; Holton, J.; Sharvell, Y.; Patel, G.; Brink, N.S. Community-based respiratory viral infections in HIV positive patients with lower respiratory tract disease: A prospective bronchoscopic study. Genitourin Med. 1996, 72, 9-11. [CrossRef] [PubMed]

20. Hawkinson, D.J.; Ison, M.G. Respiratory viruses: Influenza, RSV, and adenovirus in kidney transplantation. Semin. Nephrol. 2016, 36, 417-427. [CrossRef] [PubMed]

21. Hall, C.B.; Walsh, E.E.; Long, C.E.; Schnabel, K.C. Immunity to and frequency of reinfection with respiratory syncytial virus. J. Infect. Dis. 1991, 163, 4. [CrossRef]

22. Bont, L.; Versteegh, J.; Swelsen, W.T.; Heijnen, C.J.; Kavelaars, A.; Brus, F.; Draaisma, J.M.; Pekelharing-Berghuis, M.; van Diemen-Steenvoorde, R.A.; Kimpen, J.L. Natural reinfection with respiratory syncytial virus does not boost virus-specific T cell immunity. Pediatr. Res. 2002, 52, 363-367. [CrossRef] [PubMed]

23. Hacking, D.; Hull, J. Respiratory syncytial virus-Viral biology and the host response. J. Infect. 2002, 45, 18-24. [CrossRef] [PubMed]

24. Collins, P.; Chanock, R.; Murphy, B. Respiratory Syncytial Virus; Lippincott Williams \& Wilkins: Philadelphia, PA, USA, 2001.

25. Collins, P.L.; Fearns, R.; Graham, B.S. Respiratory syncytial virus: Virology, reverse genetics, and pathogenesis of disease. Curr. Top. Microbiol. Immunol. 2013, 372, 3-38. [PubMed]

26. Fuentes, S.; Tran, K.C.; Luthra, P.; Teng, M.N.; He, B. Function of the respiratory syncytial virus small hydrophobic protein. J. Virol. 2007, 81, 8361-8366. [CrossRef] [PubMed]

27. Mastrangelo, P.; Hegele, R.G. RSV fusion: Time for a new model. Viruses 2013, 5, 873-885. [CrossRef] [PubMed]

28. McLellan, J.S.; Chen, M.; Joyce, M.G.; Sastry, M.; Stewart-Jones, G.B.; Yang, Y.; Zhang, B.; Chen, L.; Srivatsan, S.; Zheng, A.; et al. Structure-based design of a fusion glycoprotein vaccine for respiratory syncytial virus. Science 2013, 342, 592-598. [CrossRef] [PubMed]

29. Behera, A.K.; Matsuse, H.; Kumar, M.; Kong, X.; Lockey, R.F.; Mohapatra, S.S. Blocking intercellular adhesion molecule-1 on human epithelial cells decreases respiratory syncytial virus infection. Biochem. Biophys. Res. Commun. 2001, 280, 188-195. [CrossRef] [PubMed]

30. Marr, N.; Turvey, S.E. Role of human TLR4 in respiratory syncytial virus-induced NF- $\kappa B$ activation, viral entry and replication. Innate Immun. 2012, 18, 856-865. [CrossRef] [PubMed]

31. Feldman, S.A.; Hendry, R.M.; Beeler, J.A. Identification of a linear heparin binding domain for human respiratory syncytial virus attachment glycoprotein G. J. Virol. 1999, 73, 6610-6617. [PubMed]

32. Malhotra, R.; Ward, M.; Bright, H.; Priest, R.; Foster, M.R.; Hurle, M.; Blair, E.; Bird, M. Isolation and characterisation of potential respiratory syncytial virus receptor(s) on epithelial cells. Microbes Infect. 2003, 5, 123-133. [CrossRef]

33. Araujo, G.C.; Silva, R.H.; Scott, L.P.; Araujo, A.S.; Souza, F.P.; de Oliveira, R.J. Structure and functional dynamics characterization of the ion channel of the human respiratory syncytial virus (HRSV) small hydrophobic protein (SH) transmembrane domain by combining molecular dynamics with excited normal modes. J. Mol. Model. 2016, 22, 286. [CrossRef] [PubMed]

34. Lu, B.; Ma, C.H.; Brazas, R.; Jin, H. The major phosphorylation sites of the respiratory syncytial virus phosphoprotein are dispensable for virus replication in vitro. J. Virol. 2002, 76, 10776-10784. [CrossRef] [PubMed]

35. Ouizougun-Oubari, M.; Pereira, N.; Tarus, B.; Galloux, M.; Lassoued, S.; Fix, J.; Tortorici, M.A.; Hoos, S.; Baron, B.; England, P.; et al. A druggable pocket at the nucleocapsid/phosphoprotein interaction site of human respiratory syncytial virus. J. Virol. 2015, 89, 11129-11143. [CrossRef] [PubMed]

36. Tawar, R.G.; Duquerroy, S.; Vonrhein, C.; Varela, P.F.; Damier-Piolle, L.; Castagné, N.; MacLellan, K.; Bedouelle, H.; Bricogne, G.; Bhella, D.; et al. Crystal structure of a nucleocapsid-like nucleoprotein-RNA complex of respiratory syncytial virus. Science 2009, 326, 1279-1283. [CrossRef] [PubMed]

37. Fearns, R.; Collins, P.L. Role of the M2-1 transcription antitermination protein of respiratory syncytial virus in sequential transcription. J. Virol. 1999, 73, 5852-5864. [PubMed]

38. Bermingham, A.; Collins, P.L. The M2-2 protein of human respiratory syncytial virus is a regulatory factor involved in the balance between rna replication and transcription. Proc. Natl. Acad. Sci. USA 1999, 96, 11259-11264. [CrossRef] [PubMed] 
39. Bendelja, K.; Gagro, A.; Bace, A.; Lokar-Kolbas, R.; Krsulovic-Hresic, V.; Drazenovic, V.; Mlinaric-Galinovic, G.; Rabatic, S. Predominant type-2 response in infants with respiratory syncytial virus (RSV) infection demonstrated by cytokine flow cytometry. Clin. Exp. Immunol. 2000, 121, 332-338. [CrossRef] [PubMed]

40. Aoyagi, M.; Shimojo, N.; Sekine, K.; Nishimuta, T.; Kohno, Y. Respiratory syncytial virus infection suppresses IFN- $\gamma$ production of $\gamma \delta$ T cells. Clin. Exp. Immunol. 2003, 131, 312-317. [CrossRef] [PubMed]

41. Pickles, R.J.; DeVincenzo, J.P. Respiratory syncytial virus (RSV) and its propensity for causing bronchiolitis. J. Pathol. 2015, 235, 266-276. [CrossRef] [PubMed]

42. Zeng, R.; Cui, Y.; Hai, Y.; Liu, Y. Pattern recognition receptors for respiratory syncytial virus infection and design of vaccines. Virus Res. 2012, 167, 138-145. [CrossRef] [PubMed]

43. Kurt-Jones, E.A.; Popova, L.; Kwinn, L.; Haynes, L.M.; Jones, L.P.; Tripp, R.A.; Walsh, E.E.; Freeman, M.W.; Golenbock, D.T.; Anderson, L.J.; et al. Pattern recognition receptors TLR4 and CD14 mediate response to respiratory syncytial virus. Nat. Immunol. 2000, 1, 398-401. [CrossRef] [PubMed]

44. Tayyari, F.; Marchant, D.; Moraes, T.J.; Duan, W.; Mastrangelo, P.; Hegele, R.G. Identification of nucleolin as a cellular receptor for human respiratory syncytial virus. Nat. Med. 2011, 17, 1132-1135. [CrossRef] [PubMed]

45. Triantafilou, K.; Kar, S.; Vakakis, E.; Kotecha, S.; Triantafilou, M. Human respiratory syncytial virus viroporin SH: A viral recognition pathway used by the host to signal inflammasome activation. Thorax 2013, 68, 66-75. [CrossRef] [PubMed]

46. Lifland, A.W.; Jung, J.; Alonas, E.; Zurla, C.; Crowe, J.E., Jr.; Santangelo, P.J. Human respiratory syncytial virus nucleoprotein and inclusion bodies antagonize the innate immune response mediated by MDA5 and MAVS. J. Virol. 2012, 86, 8245-8258. [CrossRef] [PubMed]

47. Kanneganti, T.D. Central roles of nlrs and inflammasomes in viral infection. Nat. Rev. Immunol. 2010, 10, 688-698. [CrossRef] [PubMed]

48. Segovia, J.; Sabbah, A.; Mgbemena, V.; Tsai, S.Y.; Chang, T.H.; Berton, M.T.; Morris, I.R.; Allen, I.C.; Ting, J.P.; Bose, S. TLR2/MYD88/NF-kB pathway, reactive oxygen species, potassium efflux activates NLRP3/ASC inflammasome during respiratory syncytial virus infection. PLoS ONE 2012, 7, e29695. [CrossRef] [PubMed]

49. Bartz, H.; Buning-Pfaue, F.; Turkel, O.; Schauer, U. Respiratory syncytial virus induces prostaglandin E2, IL-10 and IL-11 generation in antigen presenting cells. Clin. Exp. Immunol. 2002, 129, 438-445. [CrossRef] [PubMed]

50. Qiao, J.; Li, A.; Jin, X. TSLP from RSV-stimulated rat airway epithelial cells activates myeloid dendritic cells. Immunol. Cell Biol. 2011, 89, 231-238. [CrossRef] [PubMed]

51. Guerrero-Plata, A.; Casola, A.; Suarez, G.; Yu, X.; Spetch, L.; Peeples, M.E.; Garofalo, R.P. Differential response of dendritic cells to human metapneumovirus and respiratory syncytial virus. Am. J. Respir. Cell Mol. Biol. 2006, 34, 320-329. [CrossRef] [PubMed]

52. Liu, J.; Wu, J.; Qi, F.; Zeng, S.; Xu, L.; Hu, H.; Wang, D.; Liu, B. Natural helper cells contribute to pulmonary eosinophilia by producing IL-13 via IL-33/ST2 pathway in a murine model of respiratory syncytial virus infection. Int. Immunopharmacol. 2015, 28, 337-343. [CrossRef] [PubMed]

53. Zeng, S.; Wu, J.; Liu, J.; Qi, F.; Liu, B. IL-33 receptor (ST2) signalling is important for regulation of TH2-mediated airway inflammation in a murine model of acute respiratory syncytial virus infection. Scand. J. Immunol. 2015, 81, 494-501. [CrossRef] [PubMed]

54. Lee, H.C.; Headley, M.B.; Loo, Y.M.; Berlin, A.; Gale, M.J.; Debley, J.S.; Lukacs, N.W.; Ziegler, S.F. Thymic stromal lymphopoietin is induced by respiratory syncytial virus-infected airway epithelial cells and promotes a type 2 response to infection. J. Allergy Clin. Immunol. 2012, 130, 1187-1196. [CrossRef] [PubMed]

55. Dakhama, A.; Park, J.W.; Taube, C.; Joetham, A.; Balhorn, A.; Miyahara, N.; Takeda, K.; Gelfand, E.W. The enhancement or prevention of airway hyperresponsiveness during reinfection with respiratory syncytial virus is critically dependent on the age at first infection and IL-13 production. J. Immunol. 2005, 175, 1876-1883. [CrossRef] [PubMed]

56. Jeong, K.I.; Piepenhagen, P.A.; Kishko, M.; DiNapoli, J.M.; Groppo, R.P.; Zhang, L.; Almond, J.; Kleanthous, H.; Delagrave, S.; Parrington, M. Cx3cr1 is expressed in differentiated human ciliated airway cells and co-localizes with respiratory syncytial virus on cilia in a $\mathrm{G}$ protein-dependent manner. PLoS ONE 2015, 10, e0130517. [CrossRef] [PubMed] 
57. Kristjansson, S.; Bjarnarson, S.P.; Wennergren, G.; Palsdottir, A.H.; Arnadottir, T.; Haraldsson, A.; Jonsdottir, I. Respiratory syncytial virus and other respiratory viruses during the first 3 months of life promote a local TH2-like response. J. Allergy Clin. Immunol. 2005, 116, 805-811. [CrossRef] [PubMed]

58. Becker, Y. Respiratory syncytial virus (RSV) evades the human adaptive immune system by skewing the $\mathrm{TH} 1 / \mathrm{TH} 2$ cytokine balance toward increased levels of TH2 cytokines and ige, markers of allergy-A review. Virus Genes 2006, 33, 235-252. [PubMed]

59. Stoppelenburg, A.J.; Salimi, V.; Hennus, M.; Plantinga, M.; Huis, R.; Walk, J.; Meerding, J.; Coenjaerts, F.; Bont, L.; Boes, M. Local IL-17a potentiates early neutrophil recruitment to the respiratory tract during severe RSV infection. PLoS ONE 2013, 8, e78461. [CrossRef] [PubMed]

60. Faber, T.E.; Groen, H.; Welfing, M.; Jansen, K.J.; Bont, L.J. Specific increase in local IL-17 production during recovery from primary RSV bronchiolitis. J. Med. Virol. 2012, 84, 1084-1088. [CrossRef] [PubMed]

61. Saghafian-Hedengren, S.; Mathew, J.L.; Hagel, E.; Singhi, S.; Ray, P.; Ygberg, S.; Nilsson, A. Assessment of cytokine and chemokine signatures as potential biomarkers of childhood community-acquired pneumonia severity: A nested cohort study in India. Pediatr. Infect. Dis. J. 2017, 36, 102-108. [CrossRef] [PubMed]

62. Spann, K.M.; Tran, K.C.; Collins, P.L. Effects of nonstructural proteins NS1 and NS2 of human respiratory syncytial virus on interferon regulatory factor 3, NF-kB, and proinflammatory cytokines. J. Virol. 2005, 79, 5353-5362. [CrossRef] [PubMed]

63. Wright, P.F.; Karron, R.A.; Madhi, S.A.; Treanor, J.J.; King, J.C.; O'Shea, A.; Ikizler, M.R.; Zhu, Y.; Collins, P.L.; Cutland, C.; et al. The interferon antagonist NS2 protein of respiratory syncytial virus is an important virulence determinant for humans. J. Infect. Dis. 2006, 193, 573-581. [CrossRef] [PubMed]

64. Munir, S.; le Nouen, C.; Luongo, C.; Buchholz, U.J.; Collins, P.L.; Bukreyev, A. Nonstructural proteins 1 and 2 of respiratory syncytial virus suppress maturation of human dendritic cells. J. Virol. 2008, 82, 8780-8796. [CrossRef] [PubMed]

65. Le Nouën, C.; Munir, S.; Losq, S.; Winter, C.C.; McCarty, T.; Stephany, D.A.; Holmes, K.L.; Bukreyev, A.; Rabin, R.L.; Collins, P.L.; et al. Infection and maturation of monocyte-derived human dendritic cells by human respiratory syncytial virus, human metapneumovirus, and human parainfluenza virus type 3. Virology 2009, 385, 169-182. [CrossRef] [PubMed]

66. Wu, W.; Tran, K.C.; Teng, M.N.; Heesom, K.J.; Matthews, D.A.; Barr, J.N.; Hiscox, J.A. The interactome of the human respiratory syncytial virus NS1 protein highlights multiple effects on host cell biology. J. Virol. 2012, 86, 7777-7789. [CrossRef] [PubMed]

67. Gonzalez, P.A.; Bueno, S.M.; Riedel, C.A.; Kalergis, A.M. Impairment of T cell immunity by the respiratory syncytial virus: Targeting virulence mechanisms for therapy and prophylaxis. Curr. Med. Chem. 2009, 16, 4609-4625. [CrossRef] [PubMed]

68. Chang, J.; Braciale, T.J. Respiratory syncytial virus infection suppresses lung CD8 ${ }^{+} \mathrm{T}$ cell effector activity and peripheral CD8 ${ }^{+} \mathrm{T}$ cell memory in the respiratory tract. Nat. Med. 2002, 8, 54-60. [CrossRef] [PubMed]

69. Gonzalez, P.A.; Prado, C.E.; Leiva, E.D.; Carreno, L.J.; Bueno, S.M.; Riedel, C.A.; Kalergis, A.M. Respiratory syncytial virus impairs $\mathrm{T}$ cell activation by preventing synapse assembly with dendritic cells. Proc. Natl. Acad. Sci. USA 2008, 105, 14999-15004. [CrossRef] [PubMed]

70. Cespedes, P.F.; Bueno, S.M.; Ramirez, B.A.; Gomez, R.S.; Riquelme, S.A.; Palavecino, C.E.; Mackern-Oberti, J.P.; Mora, J.E.; Depoil, D.; Sacristan, C.; et al. Surface expression of the HRSV nucleoprotein impairs immunological synapse formation with T cells. Proc. Natl. Acad. Sci. USA 2014, 111, E3214-E3223. [CrossRef] [PubMed]

71. Bueno, S.M.; Gonzalez, P.A.; Cautivo, K.M.; Mora, J.E.; Leiva, E.D.; Tobar, H.E. Protective T cell immunity against respiratory syncytial virus is efficiently induced by recombinant BCG. Proc. Natl. Acad. Sci. USA 2008, 105, 20822-20827. [CrossRef] [PubMed]

72. Cherrie, A.H.; Anderson, K.; Wertz, G.W.; Openshaw, P.J. Human cytotoxic T cells stimulated by antigen on dendritic cells recognize the N, SH, F, M, 22K, and 1B proteins of respiratory syncytial virus. J. Virol. 1992, 66, 2102-2110. [PubMed]

73. Bangham, C.R.M.; Openshaw, P.J.M.; Ball, L.A.; King, A.M.Q.; Wertz, G.W.; Askonas, B.A. Human and murine cytotoxic $T$ cells specific to respiratory syncytial virus recognise the viral nucleoprotein $(\mathrm{N})$ but not the major glycoprotein (G), expressed by vaccinia virus recombinants. J. Immunol. 1986, 137, 3973-3977. [PubMed] 
74. Tregoning, J.S.; Yamaguchi, Y.; Harker, J.; Wang, B.; Openshaw, P.J. The role of T cells in the enhancement of respiratory syncytial virus infection severity during adult reinfection of neonatally sensitized mice. J. Virol. 2008, 82, 4115-4124. [CrossRef] [PubMed]

75. Lee, D.C.; Harker, J.A.; Tregoning, J.S.; Atabani, S.F.; Johansson, C.; Schwarze, J.; Openshaw, P.J. CD25 ${ }^{+}$ natural regulatory $\mathrm{T}$ cells are critical in limiting innate and adaptive immunity and resolving disease following respiratory syncytial virus infection. J. Virol. 2010, 84, 8790-8798. [CrossRef] [PubMed]

76. Durant, L.R.; Makris, S.; Voorburg, C.M.; Loebbermann, J.; Johansson, C.; Openshaw, P.J. Regulatory T cells prevent TH2 immune responses and pulmonary eosinophilia during respiratory syncytial virus infection in mice. J. Virol. 2013, 87, 10946-10954. [CrossRef] [PubMed]

77. Resch, B. Respiratory syncytial virus infection in high-risk infants—An update on palivizumab prophylaxis. Open Microbiol. J. 2014, 8, 71-77. [CrossRef] [PubMed]

78. Huang, K.; Incognito, L.; Cheng, X.; Ulbrandt, N.D.; Wu, H. Respiratory syncytial virus-neutralizing monoclonal antibodies motavizumab and palivizumab inhibit fusion. J. Virol. 2010, 84, 8132-8140. [CrossRef] [PubMed]

79. The IMpact-RSV Study Group. Palivizumab, a humanized respiratory syncytial virus monoclonal antibody, reduces hospitalization from respiratory syncytial virus infection in high-risk infants. Pediatrics 1998, 102, 531-537.

80. Ambrose, C.S.; Chen, X.; Kumar, V.R. A population-weighted, condition-adjusted estimate of palivizumab efficacy in preventing RSV-related hospitalizations among US high-risk children. Hum. Vaccin. Immunother. 2014, 10, 2785-2788. [CrossRef] [PubMed]

81. Chen, J.J.; Chan, P.; Paes, B.; Mitchell, I.; Li, A.; Lanctôt, K.L.; CARESS investigators. Serious adverse events in the Canadian registry of children receiving palivizumab (CARESS) for respiratory syncytial virus prevention. PLoS ONE 2015, 10, e0134711. [CrossRef] [PubMed]

82. Wu, H.; Pfarr, D.S.; Tang, Y.; An, L.L.; Patel, N.K.; Watkins, J.D.; Huse, W.D.; Kiener, P.A.; Young, J.F. Ultra-potent antibodies against respiratory syncytial virus: Effects of binding kinetics and binding valence on viral neutralization. J. Mol. Biol. 2005, 350, 126-144. [CrossRef] [PubMed]

83. Mejías, A.; Chávez-Bueno, S.; Ríos, A.M.; Aten, M.F.; Raynor, B.; Peromingo, E.; Soni, P.; Olsen, K.D.; Kiener, P.A.; Gómez, A.M.; et al. Comparative effects of two neutralizing anti-respiratory syncytial virus (RSV) monoclonal antibodies in the RSV murine model: Time versus potency. Antimicrob. Agents Chemother. 2005, 49, 4700-4707. [CrossRef] [PubMed]

84. Carbonell-Estrany, X.; Simões, E.A.; Dagan, R.; Hall, C.B.; Harris, B.; Hultquist, M.; Connor, E.M.; Losonsky, G.A. Motavizumab for prophylaxis of respiratory syncytial virus in high-risk children: A noninferiority trial. Pediatrics. 2010, 125, e35-e51. [CrossRef] [PubMed]

85. Fernández, P.; Trenholme, A.; Abarca, K.; Griffin, M.P.; Hultquist, M.; Harris, B.; Losonsky, G.A. A phase 2, randomized, double-blind safety and pharmacokinetic assessment of respiratory syncytial virus (RSV) prophylaxis with motavizumab and palivizumab administered in the same season. BMC Pediatr. 2010, 10, 38. [CrossRef] [PubMed]

86. Lagos, R.; DeVincenzo, J.P.; Muñoz, A.; Hultquist, M.; Suzich, J.; Connor, E.M.; Losonsky, G.A. Safety and antiviral activity of motavizumab, a respiratory syncytial virus (RSV)-specific humanized monoclonal antibody, when administered to RSV-infected children. Pediatr. Infect. Dis. J. 2009, 28, 835-837. [CrossRef] [PubMed]

87. Ramilo, O.; Lagos, R.; Sáez-Llorens, X.; Suzich, J.; Wang, C.K.; Jensen, K.M.; Harris, B.S.; Losonsky, G.A.; Griffin, M.P. Motavizumab treatment of infants hospitalized with respiratory syncytial virus infection does not decrease viral load or severity of illness. Pediatr. Infect. Dis. J. 2014, 33, 703-709. [CrossRef] [PubMed]

88. Clinicaltrials.gob. Nct00129766. Avaliable online: https://clinicaltrials.gov/ct2/show/NCT00129766 (accessed on 28 February 2017).

89. Robbie, G.J.; Criste, R.; Dall'acqua, W.F.; Jensen, K.; Patel, N.K.; Losonsky, G.A.; Griffin, M.P. A novel investigational Fc-modified humanized monoclonal antibody, motavizumab-YTE, has an extended half-life in healthy adults. Antimicrob. Agents Chemother. 2013, 57, 6147-6153. [CrossRef] [PubMed]

90. Griffin, M.P.; Khan, A.A.; Esser, M.T.; Jensen, K.; Takas, T.; Kankam, M.K.; Villafana, T.; Dubovsky, F. Safety, tolerability, and pharmacokinetics of the respiratory syncytial virus-prefusion F-targeting monoclonal antibody with an extended half-life, MEDI8897, in healthy adults. Antimicrob. Agents Chemother. 2016. [CrossRef] [PubMed] 
91. Clinicaltrials.gob. Nct02878330. Avaliable online: https://clinicaltrials.gov/ct2/show/NCT02878330 (accessed on 28 February 2017).

92. Haynes, L.M.; Caidi, H.; Radu, G.U.; Miao, C.; Harcourt, J.L.; Tripp, R.A.; Anderson, L.J. Therapeutic monoclonal antibody treatment targeting respiratory syncytial virus (RSV) G protein mediates viral clearance and reduces the pathogenesis of RSV infection in BALB/c mice. J. Infect. Dis. 2009, 200, 439-447. [CrossRef] [PubMed]

93. Han, J.; Takeda, K.; Wang, M.; Zeng, W.; Jia, Y.; Shiraishi, Y.; Okamoto, M.; Dakhama, A.; Gelfand, E.W. Effects of anti-G and anti-F antibodies on airway function after respiratory syncytial virus infection. Am. J. Respir. Cell Mol. Biol. 2014, 51, 143-154. [CrossRef]

94. Munoz, F.M.; Piedra, P.A.; Glezen, W.P. Safety and immunogenicity of respiratory syncytial virus purified fusion protein-2 vaccine in pregnant women. Vaccine 2003, 21, 3465-3467. [CrossRef]

95. Blanco, J.C.G.; Pletneva, L.M.; Oue, R.O.; Patel, M.C.; Boukhvalovaa, M.S. Maternal transfer of RSV immunity in cotton rats vaccinated during pregnancy. Vaccine 2015, 33, 5371-5379. [CrossRef] [PubMed]

96. Garg, R.; Latimer, L.; Wang, Y.; Simko, E.; Gerdts, V.; Potter, A. Maternal immunization with respiratory syncytial virus fusion protein formulated with a novel combination adjuvant provides protection from RSV in newborn lambs. Vaccine 2016, 34, 261-269. [CrossRef] [PubMed]

97. Glenn, G.M.; Fries, L.F.; Thomas, D.N.; Smith, G.; Kpamegan, E.; Lu, H.; Flyer, D.; Jani, D.; Hickman, S.P.; Piedra, P.A. A randomized, blinded, controlled, dose-ranging study of a respiratory syncytial virus recombinant fusion (F) nanoparticle vaccine in healthy women of childbearing age. J. Infect. Dis. 2016, 213, 411-422. [CrossRef] [PubMed]

98. Clinicaltrials.gob. Nct02624947. Avaliable online: https://clinicaltrials.gov/ct2/show/NCT02624947 (accessed on 28 February 2017).

99. Clinicaltrials.gob. Nct02608502. Avaliable online: https://clinicaltrials.gov/ct2/show/NCT02608502 (accessed on 28 February 2017).

100. Kruijsen, D.; Schijf, M.A.; Lukens, M.V.; Uden, N.O.V.; Kimpen, J.L.; Coenjaerts, F.E.; Bleek, G.M.V. Local innate and adaptive immune responses regulate inflammatory cell influx into the lungs after vaccination with formalin inactivated RSV. Vaccine 2011, 29, 2730-2741. [CrossRef] [PubMed]

101. Kim, H.W.; Canchola, J.G.; Brandt, C.D.; Pyles, G.; Chanock, R.M.; Jensen, K.; Parrott, R.H. Respiratory syncytial virus disease in infants despite prior administration of antigenic inactivated vaccine. Am. J. Epidemiol. 1969, 89, 422-434. [CrossRef] [PubMed]

102. Kapikian, A.Z.; Mitchell, R.H.; Chanock, R.M.; Shvedoff, R.A.; Stewart, C.E. An epidemiologic study of altered clinical reactivity to respiratory syncytial (RS) virus infection in children previously vaccinated with an inactivated RS virus vaccine. Am. J. Epidemiol. 1969, 89, 405-421. [CrossRef] [PubMed]

103. PATH. Respiratory Syncytial Virus. Vaccine Development against a Major Cause of Childhood Respiratory Illness. Available online: http://sites.Path.Org/vaccinedevelopment/respiratory-syncytial-virus-rsv (accessed on 17 Febreary 2017).

104. Hwang, H.S.; Kwon, Y.M.; Lee, J.S.; Yoo, S.E.; Lee, Y.N.; Ko, E.J.; Kim, M.C.; Cho, M.K.; Lee, Y.T.; Jung, Y.J.; et al. Co-immunization with virus-like particle and DNA vaccines induces protection against respiratory syncytial virus infection and bronchiolitis. Antiviral Res. 2014, 110, 115-123. [CrossRef] [PubMed]

105. Xu, J.; Ding, Y.; Yang, Y. Enhancement of mucosal and cellular immune response in mice by vaccination with respiratory syncytial virus DNA encapsulated with transfersome. Viral Immunol. 2008, 21, 483-490.

106. Liang, B.; Ngwuta, J.O.; Herbert, R.; Swerczek, J.; Dorward, D.W.; Amaro-Carambot, E.; Mackow, N.; Kabatova, B.; Lingemann, M.; Surman, S.; et al. Packaging and prefusion stabilization separately and additively increase the quantity and quality of respiratory syncytial virus (RSV)-neutralizing antibodies induced by an RSV fusion protein expressed by a parainfluenza virus vector. J. Virol. 2016, 90, 10022-10038. [CrossRef] [PubMed]

107. Cautivo, K.M.; Bueno, S.M.; Cortes, C.M.; Wozniak, A.; Riedel, C.A.; Kalergis, A.M. Efficient lung recruitment of respiratory syncytial virusspecific TH1 cells induced by recombinant bacillus calmette-guerin promotes virus clearance and protects from infection. J. Immunol. 2010, 185, 7633-7645. [CrossRef]

108. Céspedes, P.C.; Rey-Jurado, E.; Espinoza, J.A.; Rivera, C.A.; Canedo-Marroquín, G.; Bueno, S.M.; Kalergis, A. A single, low dose of a CGMP recombinant BCG vaccine elicits protective $\mathrm{T}$ cell immunity against the human respiratory syncytial virus infection and prevents lung pathology in mice. Vaccine 2016. [CrossRef] [PubMed] 
109. Karron, R.A.; Luongo, C.; Thumar, B.; Loehr, K.M.; Englund, J.A.; Collins, P.L.; Buchholz, U.J. A gene deletion that up-regulates viral gene expression yields an attenuated RSV vaccine with improved antibody responses in children. Sci. Transl. Med. 2015, 7, 175. [CrossRef] [PubMed]

110. Luongo, C.; Winter, C.C.; Collins, P.L.; Buchholz, U.J. Respiratory syncytial virus modified by deletions of the NS2 gene and amino acid S1313 of the L polymerase protein is a temperature-sensitive, live-attenuated vaccine candidate that is phenotypically stable at physiological temperature. J. Virol. 2013, 87, 1985-1996. [CrossRef]

111. Jones, B.G.; Sealy, R.E.; Surman, S.L.; Portner, A.; Russell, C.J.; Slobod, K.S.; Dormitzer, P.R.; DeVincenzo, J.; Hurwitz, J.L. Sendai virus-based RSV vaccine protects against RSV challenge in an in vivo maternal antibody model. Vaccine 2014, 32, 3264-3273. [CrossRef] [PubMed]

112. Widjojoatmodjo, M.N.; Boes, J.; van Bers, M.; van Remmerden, Y.; Roholl, P.J.; Luytjes, W. A highly attenuated recombinant human respiratory syncytial virus lacking the $\mathrm{G}$ protein induces long-lasting protection in cotton rats. Virol. J. 2010, 2, 114. [CrossRef] [PubMed]

113. Lindell, D.M.; Morris, S.B.; White, M.P.; Kallal, L.E.; Lundy, P.K.; Hamouda, T.; Baker, J.J.; Lukacs, N.W. A novel inactivated intranasal respiratory syncytial virus vaccine promotes viral clearance without TH2 associated vaccine-enhanced disease. PLoS ONE 2011, 6, e21823. [CrossRef] [PubMed]

114. Cimica, V.; Boigard, H.; Bhatia, B.; Fallon, J.T.; Alimova, A.; Gottlieb, P.; Galarza, J.M. Novel respiratory syncytial virus-like particle vaccine composed of the postfusion and prefusion conformations of the $\mathrm{F}$ glycoprotein. Clin. Vaccine Immunol. 2016, 23, 451-459. [CrossRef] [PubMed]

115. Schmidt, M.R.; McGinnes-Cullen, L.W.; Kenward, S.A.; Willems, K.N.; Woodland, R.T.; Morrison, T.G. Modification of the respiratory syncytial virus F protein in virus-like particles impacts generation of B cell memory. J. Virol. 2014, 88, 10165-10176. [CrossRef] [PubMed]

116. Li, C.; Zhou, X.; Zhong, Y.; Li, C.; Dong, A.; He, Z.; Zhang, S.; Wang, B. A recombinant G protein plus cyclosporine A-based respiratory syncytial virus vaccine elicits humoral and regulatory $\mathrm{T}$ cell responses against infection without vaccine-enhanced disease. J. Immunol. February 2016, 196, 1721-1731. [CrossRef] [PubMed]

117. Krarup, A.; Truan, D.; Furmanova-Hollenstein, P.; Bogaert, L.; Bouchier, P.; Bisschop, I.J.; Widjojoatmodjo, M.N.; Zahn, R.; Schuitemaker, H.; McLellan, J.S.; et al. A highly stable prefusion RSV F vaccine derived from structural analysis of the fusion mechanism. Nat. Commun. 2015, 3, 8143. [CrossRef] [PubMed]

118. Rigter, A.; Widjaja, I.; Versantvoort, H.; Coenjaerts, F.E.; van Roosmalen, M.; Leenhouts, K.; Rottier, P.J.; Haijema, B.J.; de Haan, C.A. A protective and safe intranasal RSV vaccine based on a recombinant prefusion-like form of the F protein bound to bacterium-like particles. PLoS ONE 2013, 8, e71072.

119. Clinicaltrials.gob. Nct02958540. Avaliable online: https://clinicaltrials.gov/ct2/show/NCT02958540 (accessed on 28 February 2017).

120. Hervé, P.L.; Deloizy, C.; Descamps, D.; Rameix-Welti, M.A.; Fix, J.; McLellan, J.S.; Eléouët, J.F.; Riffault, S. RSV $\mathrm{N}$-nanorings fused to palivizumab-targeted neutralizing epitope as a nanoparticle RSV vaccine. Nanomedicine 2016, 9634, 30114-30119. [CrossRef] [PubMed]

121. Hervé, P.L.; Descamps, D.; Deloizy, C.; Dhelft, V.; Laubreton, D.; Bouguyon, E.; Boukadiri, A.; Dubuquoy, C.; Larcher, T.; Benhamou, P.H.; et al. Non-invasive epicutaneous vaccine against respiratory syncytial virus: Preclinical proof of concept. J. Control. Release. 2016, 243, 146-159. [CrossRef] [PubMed]

122. Zhang, W.; Choi, Y.; Haynes, L.M.; Harcourt, J.L.; Anderson, L.J.; Jones, L.P.; Tripp, R.A. Vaccination to induce antibodies blocking the CX3C-CX3CR1 interaction of respiratory syncytial virus $\mathrm{G}$ protein reduces pulmonary inflammation and virus replication in mice. J. Virol. 2010, 84, 1148-1157. [CrossRef] [PubMed]

123. Palomo, C.; Mas, V.; Thom, M.; Vázquez, M.; Cano, O.; Terrón, M.C.; Luque, D.; Taylor, G.; Melero, J.A. Influence of RSV F glycoprotein conformation on induction of protective immune responses. J. Virol. 2016, 90, 5485-5498. [CrossRef] [PubMed]

124. Langley, J.M.; Aggarwal, N.; Toma, A.; Halperin, S.A.; McNeil, S.A.; Fissette, L.; Dewé, W.; Leyssen, M.; Toussaint, J.F.; Dieussaert, I. A randomized, controlled, observer-blinded phase 1 study of the safety and immunogenicity of a respiratory syncytial virus vaccine with or without alum adjuvant. J. Infect. Dis. 2017, 215, 24-33. [CrossRef] [PubMed] 
125. Grunwald, T.; Tenbusch, M.; Schulte, R.; Raue, K.; Wolf, H.; Hannaman, D.; de Swart, R.L.; Uberla, K.; Stahl-Hennig, C. Novel vaccine regimen elicits strong airway immune responses and control of respiratory syncytial virus in nonhuman primatesj virol. J. Virol. 2014, 88, 3997-4007. [CrossRef] [PubMed]

126. Shao, H.Y.; Hsu, H.S.; Yu, S.L.; Wu, S.R.; Hu, K.C.; Chang, C.K.; Liu, C.C.; Chow, Y.H. Immunogenicity of an adeno-vector vaccine expressing the $\mathrm{F}$ protein of a respiratory syncytial virus manufactured from serum-free suspension culture. Antiviral Res. 2016, 130, 27-35. [CrossRef] [PubMed]

127. Widjojoatmodjo, M.N.; Bogaert, L.; Meek, B.; Zahn, R.; Vellinga, J.; Custers, J.; Serroyen, J.; Radošević, K.; Schuitemaker, H. Recombinant low-seroprevalent adenoviral vectors AD26 and AD35 expressing the respiratory syncytial virus (RSV) fusion protein induce protective immunity against RSV infection in cotton rats. Vaccine 2015, 33, 5406-5414. [CrossRef] [PubMed]

128. Kim, E.; Okada, K.; Beeler, J.A.; Crim, R.L.; Piedra, P.A.; Gilbert, B.E.; Gambotto, A. Development of an adenovirus-based respiratory syncytial virus vaccine: Preclinical evaluation of efficacy, immunogenicity, and enhanced disease in a cotton rat model. J. Virol. 2014, 88, 5100-5108. [CrossRef] [PubMed]

129. De Waal, L.; Wyatt, L.S.; Yüksel, S.; van Amerongen, G.; Moss, B.; Niesters, H.G.; Osterhaus, A.D.; de Swart, R.L. Vaccination of infant macaques with a recombinant modified vaccinia virus ankara expressing the respiratory syncytial virus $F$ and $G$ genes does not predispose for immunopathology. Vaccine 2004, 22, 923-926. [CrossRef] [PubMed]

130. Olszewska, W.; Suezer, Y.; Sutter, G.; Openshaw, P.J. Protective and disease-enhancing immune responses induced by recombinant modified vaccinia ankara (MVA) expressing respiratory syncytial virus proteins. Vaccine 2004, 23, 215-221. [CrossRef] [PubMed]

131. Green, C.A.; Scarselli, E.; Voysey, M.; Capone, S.; Vitelli, A.; Nicosia, A.; Cortese, R.; Thompson, A.J.; de Lara, C.; Klenerman, P.; et al. Safety and immunogenicity of novel respiratory syncytial virus (RSV) vaccines based on the RSV viral proteins F, N and M2-1 encoded by simian adenovirus (PanAd3-RSV) and MVA (MVA-RSV); protocol for an open-label, dose-escalation, single-centre, phase 1 clinical trial in healthy adults. BMJ Open 2015, 5, e008748. [PubMed]

132. Phan, S.I.; Chen, Z.; Xu, P.; Li, Z.; Gao, X.; Foster, S.L.; Teng, M.N.; Tripp, R.A.; Sakamoto, K.; He, B. A respiratory syncytial virus (RSV) vaccine based on parainfluenza virus 5 (PIV5). Vaccine 2014, 32, 3050-3057. [CrossRef] [PubMed]

133. Teng, M.N.; Whitehead, S.S.; Bermingham, A.; St Claire, M.; Elkins, W.R.; Murphy, B.R.; Collins, P.L. Recombinant respiratory syncytial virus that does not express the NS1 or M2-2 protein is highly attenuated and immunogenic in chimpanzees. J. Virol. 2000, 74, 9317-9321. [CrossRef] [PubMed]

134. Stobart, C.C.; Rostad, C.A.; Ke, Z.; Dillard, R.S.; Hampton, C.M.; Strauss, J.D.; Yi, H.; Hotard, A.L.; Meng, J.; Pickles, R.J.; et al. A live RSV vaccine with engineered thermostability is immunogenic in cotton rats despite high attenuation. Nat. Commun. 2016, 21, 13916. [CrossRef] [PubMed]

135. Bernstein, D.I.; Malkin, E.; Abughali, N.; Falloon, J.; Yi, T.; Dubovsky, F.; MI-CP149 Investigators. Phase 1 study of the safety and immunogenicity of a live, attenuated respiratory syncytial virus and parainfluenza virus type 3 vaccine in seronegative children. Pediatr. Infect. Dis. J. 2012, 31, 109-114. [CrossRef] [PubMed]

136. Liang, B.; Munir, S.; Amaro-Carambot, E.; Surman, S.; Mackow, N.; Yang, L.; Buchholz, U.J.; Collins, P.L.; Schaap-Nutt, A. Chimeric bovine/human parainfluenza virus type 3 expressing respiratory syncytial virus (RSV) F glycoprotein: Effect of insert position on expression, replication, immunogenicity, stability, and protection against RSV infection. J. Virol. 2014, 88, 4237-4250. [CrossRef] [PubMed]

137. Schmidt, A.C.; McAuliffe, J.M.; Murphy, B.R.; Collins, P.L. Recombinant bovine/human parainfluenza virus type 3 (B/HPIV3) expressing the respiratory syncytial virus (RSV) G and F proteins can be used to achieve simultaneous mucosal immunization against RSV and HPIV3. J. Virol. 2001, 75, 4594-4603. [CrossRef] [PubMed]

138. Taylor, G.; Thom, M.; Capone, S.; Pierantoni, A.; Guzman, E.; Herbert, R.; Scarselli, E.; Napolitano, F.; Giuliani, A.; Folgori, A.; et al. Efficacy of a virus-vectored vaccine against human and bovine respiratory syncytial virus infections. Sci. Transl. Med. 2015, 7, 127. [CrossRef] [PubMed]

139. Zhang, Y.; Qiao, L.; Hu, X.; Zhao, K.; Zhang, Y.; Chai, F.; Pan, Z. Baculovirus vectors expressing F proteins in combination with virus-induced signaling adaptor (VISA) molecules confer protection against respiratory syncytial virus infection. Vaccine 2016, 34, 252-260. [CrossRef] [PubMed] 
140. Kim, S.; Chang, J. Baculovirus-based vaccine displaying respiratory syncytial virus glycoprotein induces protective immunity against RSV infection without vaccine-enhanced disease. Immun. Netw. 2012, 12, 8-17. [CrossRef] [PubMed]

141. Jones, B.; Zhan, X.; Mishin, V.; Slobod, K.S.; Surman, S.; Russell, C.J.; Portner, A.; Hurwitz, J.L. Human PIV-2 recombinant Sendai virus (rSeV) elicits durable immunity and combines with two additional $\mathrm{rSeVs}$ to protect against HPIV-1, HPIV-2, HPIV-3, and RSV. Vaccine 2009, 27, 1848-1857. [CrossRef] [PubMed]

142. Green, C.A.; Scarselli, E.; Sande, C.J.; Thompson, A.J.; de Lara, C.M.; Taylor, K.S.; Haworth, K.; del Sorbo, M.; Angus, B.; Siani, L.; et al. Chimpanzee adenovirus- and MVA-vectored respiratory syncytial virus vaccine is safe and immunogenic in adults. Sci. Transl. Med. 2015, 7, 126. [CrossRef] [PubMed]

143. Hwang, H.S.; Lee, Y.T.; Kim, K.H.; Park, S.; Kwon, Y.M.; Lee, Y.; Ko, E.J.; Jung, Y.J.; Lee, J.S.; Kim, Y.J.; et al. Combined virus-like particle and fusion protein-encoding DNA vaccination of cotton rats induces protection against respiratory syncytial virus without causing vaccine-enhanced disease. Virology 2016, 494, 215-224. [CrossRef] [PubMed]

144. Schepens, B.; Sedeyn, K.; Vande Ginste, L.; de Baets, S.; Schotsaert, M.; Roose, K.; Houspie, L.; van Ranst, M.; Gilbert, B.; van Rooijen, N.; et al. Protection and mechanism of action of a novel human respiratory syncytial virus vaccine candidate based on the extracellular domain of small hydrophobic protein. EMBO Mol. Med. 2014, 6, 1436-1454. [CrossRef] [PubMed]

145. Langley, J.; Macdonald, L.; Weir, G.; Mackinnon-Cameron, D.; Lingyun Ye, L.; McNeil, S.; Schepens, B.; Saelens, X.; Stanford, M.; Scott Halperin, S. A phase I randomized, observer-blind, controlled, dose escalation trial of the safety and tolerability of two intramuscular doses of DPX-RSV(A), a respiratory syncytial virus (RSV) vaccine containing RSV SH antigen and a novel adjuvant depovax, or SH antigen co-administered with aluminum hydroxide, or placebo to healthy adults $\geq 50-64$ years of age. Open Forum Infect. Dis. 2016, 3, 1270.

146. Cheng, W. The density code for the development of a vaccine? J. Pharm. Sci. 2016, 105, 3223-3232. [CrossRef] [PubMed]

147. Glenn, G.M.; Smith, G.; Fries, L.; Raghunandan, R.; Lu, H.; Zhou, B.; Thomas, D.N.; Hickman, S.P.; Kpamegan, E.; Boddapati, S.; et al. Safety and immunogenicity of a SF9 insect cell-derived respiratory syncytial virus fusion protein nanoparticle vaccine. Vaccine 2013, 31, 524-532. [CrossRef] [PubMed]

148. Lee, Y.T.; Ko, E.J.; Hwang, H.S.; Lee, J.S.; Kim, K.H.; Kwon, Y.M.; Kang, S.M. Respiratory syncytial virus-like nanoparticle vaccination induces long-term protection without pulmonary disease by modulating cytokines and T cells partially through alveolar macrophages. Int. J. Nanomed. 2015, 14, 4491-4505.

149. Wang, D.; Cummins, C.; Bayliss, S.; Sandercock, J.; Burls, A. Immunoprophylaxis against respiratory syncytial virus (RSV) with palivizumab in children-A systematic review and economic evaluation. Health Technol. Assess. 2008, 12, 1-86. [CrossRef]

(c) 2017 by the authors. Licensee MDPI, Basel, Switzerland. This article is an open access article distributed under the terms and conditions of the Creative Commons Attribution (CC BY) license (http:/ / creativecommons.org/licenses/by/4.0/). 